Hannamari Heino \& Juha Tuunainen (2018) Heading for Decline? The Significance of Disturbances in the Strategic Management Process. International Journal of Strategic Change Management 7, 2, 139-159.

This is a self-archived version of the final published article.

\title{
Heading for decline? The significance of disturbances in strategic management process
}

\begin{abstract}
This article will address problems in strategic management process from the perspective of organizational decline. It will review the literature on early warning signals of decline and contribute to an understanding of their role in organizational development. To facilitate more advanced theorizing about early warning signals, the article will draw from cultural-historical activity theory suggesting that early warnings should be conceptualized in terms of organizational disturbances that act as visible evidence of developmental contradictions. By combining activity theory with strategy process research, the article will open up an avenue for organizational analysis to better understand the nature of weak signs of decline and provide a better basis for their resolution. The conceptualization will be illustrated by referring to a case example of a firm operating in service production.
\end{abstract}

Keywords: organizational decline, early warning signals, cultural-historical activity theory, contradiction, strategic management process 


\section{Introduction}

Early warning signals can offer a powerful lens for understanding the interconnections between different elements within and between organizations, and between organizations and their environments. The weakness of the literature discussing early warning signals stems from its rather descriptive nature (Williams et al., 2012; Mellahi, 2005; Scherrer, 2003; Milenković, 2000; Mitroff, 1988; Lorange and Nelson, 1987) and the fact that it does not foster theoretical understanding of the role of such signals in organizational decline. Because of this, we will combine cultural-historical activity theory (Engeström, 2014) with strategy process research (Goshal et al., 2013; Vaara \& Whittington, 2012; Sminia, 2009; Furrer et al., 2008; Johnson et al., 2008; Shanley \& Peteraf, 2006; Pettigrew, 1992; Mintzberg \& Quinn, 1991) to develop a theoretically sound basis for their further understanding from a dialectical perspective (Langley et al., 2013; Sminia, 2009; Van de Ven \& Poole, 2005). We will first review research on organizational strategy process and early warning signals of decline and, after that, suggest a theoretical way to analyze early warnings in terms of developmental contradictions that take place in local activity systems (Engeström, 2014; cf. Mocciaro Li Destri \& Dagnino, 2012), such as firms. We will then demonstrate the usefulness of the activity theoretical conceptuality with reference to an illustrative case example that comes from a company operating in the field of service production. Our main contribution is to combine strategy process research and analysis of early warning signals with activity theoretical conceptuality so as to facilitate a more profound theoretical understanding of the potential organizational decline.

\section{Strategy process and early warning signals of decline}


Strategic management is a process in which managers form and implement a strategy that can lead to a durable competitive advantage for a firm (Rothaermel, 2012). It is a process designed to set organizational objectives, formulate ways of meeting those objectives, implement related actions, and evaluate the achieved outcomes (Thompson \& Martin, 2010; Carroll \& Karim, 2011). Of the available models of the strategic management process (e.g., Rothaermel, 2012; Thompson \& Martin, 2010; David, 2011), we regard here the approach defined by Johnson et al. (2008) as representational with respect to our purposes. According to it, strategic management can be conceptualized in three main phases: 1) strategic position analysis of the environment, resources, competencies, stakeholder expectations and organizational purposes; 2) choice of the strategy wherein the firm chooses directions and methods of development, engages in identification and evaluation of alternatives, and selects the appropriate strategy; and 3) strategy to action where the focus is on an organization's structure and design, resource allocation, control and monitoring, as well as managing the strategic change itself.

Although seemingly rationalistic, the strategy process does not have to be regarded as a simple linear succession of phases in time but can be viewed as a complex entity with multiple interlinked actions and feedback loops (e.g., Sminia, 2009; Ericson, 2014). This is evidenced by the fact that many external and internal conditions may change, resulting in the revision of the original strategic plan (Johnson et al., 2008). However, there is not always a need to replace a plan with a new strategy to meet changed circumstances and start the process all over again, but corrections can be made based on acquired new information in a strategy revision phase. The key element in strategy revision is to distil relevant information from the changing environment and internal activities of a company. The need for revision is underlined especially today when the technologies are complex, environmental change rapid and product markets global (Boynton \& Victor, 1991). Based on this reasoning, we propose the following schematic representation of a firm's strategic management process (Figure 1). 


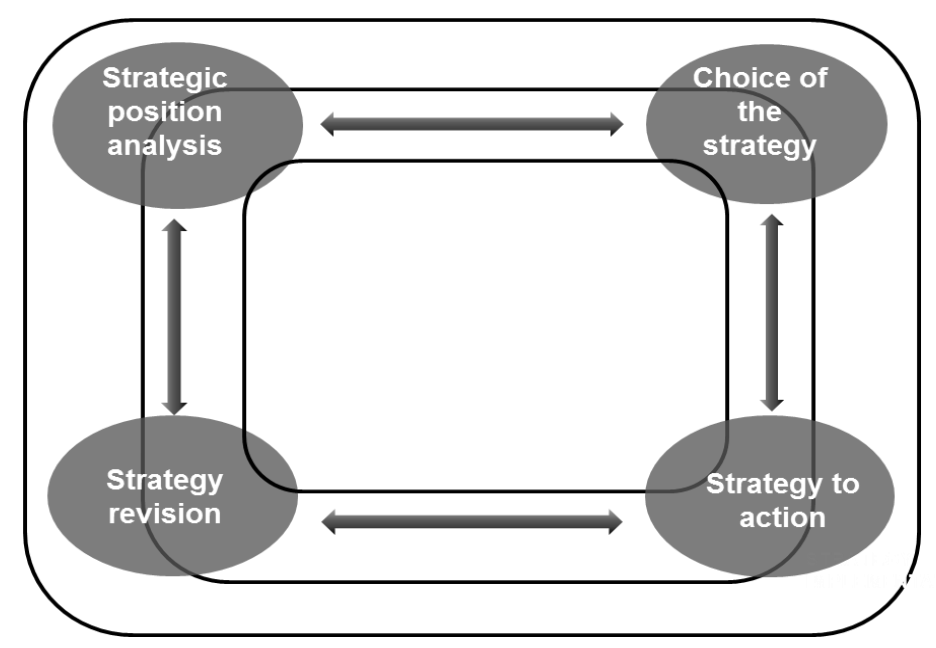

Figure 1. Strategy process (adapted from Johnson et al., 2008).

Management of strategy process is not only about building a firm's success but also preventing its slide towards a decline in performance (Maitlis \& Lawrence, 2003). Based on a processual perspective (e.g., Langley et al., 2013), decline can be regarded as taking place in various phases starting from a blinded state and leading to the final dissolution of the firm through inaction, faulty action and crisis states (Weitzel \& Jonsson, 1989). In this context, the significance of what has been called early warning signals is evident.

According to Cameron et al. (1987, p.224, cf. D'Aveni, 1989), decline is “a condition in which a substantial, absolute decrease in an organization's resource base occurs over a specified period of time". McKinley et al. (2014, p.90) further specified it as "a successive, year-after-year decrease in an organization's resource base that lasts for at least two years". In this article, we will base our understanding of the concept in Robbins and Pearce (1992), Barker and Mone (1994), Weitzel and Johnson (1989) as well as Williams et al. (2012), and define decline as a sustained process where the actual value of a company deviates from its targeted value thereby indicating underperformance of a firm's strategy. The conception is thus different from organizational 
downsizing, turbulence, crisis, stagnation and environmental jolts (see McKinley et al., 2014; D’Aveni, 1989) as well as early warnings of ethnic conflicts (Foot, 2002). In our view, decline is a rough opposite of successful organizational performance, as Heine and Rindfleisch (2013), McKinley (1993) and Whetten (1987) have argued. Later on, we will also equate it with the activity theoretical notion of a disturbance (Engeström, 2005).

Concerning the causes of decline, the literature directs attention to both external and internal reasons. Whetten (1987), for instance, underlined changes in the carrying capacity of a firm's operating niche and referred to the so-called "success-breeds-failure" syndrome, which refers to the overconfidence of managers in the abilities of a firm to dominate markets. Other scholars provide causes for this, such as the routinization of organizational practices, the lack of innovation and resistance to change (McKinley, 1993; Weitzel \& Jonsson, 1989; Cummings et al., 1983). Whatever the causes, it is important that managers responsible for a firm's strategy and operations are able to detect and understand the possible reasons early enough. That is precisely what research on early warning signals has emphasized.

In what follows, we will understand early warning signals as weak signs that hint at serious problems in a firm's future performance, or, as Williams et al. (2012, p. 38) state, observations that indicate the existence of some incipient positive or negative issues related to a firm's future performance and value. We will maintain that a successful management team should be capable of detecting and making sense of such signs and prepare the necessary actions to prevent them from materializing (Mellahi, 2005; Williams et al., 2012; Sheaffer et al., 1998; Milenković, 2001; Hambrick \& D'aveni, 1988; Lorange \& Nelson, 1987; Chong, 2004). As the literature indicates, this is not, however, always an easy thing to achieve (Mellahi, 2005; Scherrer, 2003; DeVaughn \& Leary, 2010).

To advance the management's capacity to deal with early warning signals, some scholars have provided lists or categories of them (e.g., Mitroff, 1988; Lorange \& Nelson, 1987). Because 
organizations and situations differ, such lists do not provide a durable solution to the problem of interpreting these signs but must be supplemented with a more systematic and rigorous analysis (Williams et al., 2012; Milenković, 2000; Mitroff, 1988). Hence, the research on early warnings does not provide adequate capacity to analyze and interpret the root problems behind the manifest signs of problems, a fact which makes them as valuable as a doctor knowing a list of symptoms of an unspecified illness. In a similar way, as the doctor needs to examine the causes behind the symptoms, management scholars should be able to address fundamental problems behind the apparent weak signs of decline so that they could be acted upon early enough and in an appropriate manner. To do so, we will next turn our gaze to the dialectical research tradition (Langley et al., 2013; Sminia, 2009; Van de Ven \& Poole, 2005), namely, the cultural-historical activity theory (Engeström, 2014).

\section{Conceptualizing early warning signals as contradictions in activity systems}

As noted, the goal of the notion of early warning signals is to understand possible signs of corporate decline. The problem, however, remains that the literature does not provide capacity on the basis of which fundamental problems behind such weak signs could be theoretically understood. A methodological perspective, which can be applied to further understand the signs, is thus needed. For such a perspective, we will use ideas and concepts adopted from cultural-historical activity theory (Leontjev, 1978; Vygotsky, 1978; Engeström et al., 1999; Engeström, 2014), an approach extensively used in analyzing organizational change and management (e.g., Blackler et al., 2000; Adler, 2006; Engeström, 2008a; Teräs, 2007; Kajamaa, 2015; Kerosuo et al., 2010). In so doing, we aim to illustrate an approach with which apparent problems that engender decline can be re-conceptualized so as to provide an avenue for their early recognition and resolution. 
In activity theory, organizations are typically conceptualized as object-oriented collective work activities. As discussed by Miettinen (2005), object-orientedness is a constitutive feature of human conduct as it denotes the collective societal motive of local activity, i.e., answers to the question of why a certain group of actors pursues what it does. In activity theoretical conceptuality, local activities are composed of an agent or a group of people (a subject, such as firm managers or service producers) who are working towards achieving a shared purpose, which represents their object of activity (e.g., a product or service) and the outcome which results from the construction of such an object (e.g., targeted value). The work by the subjects is mediated by material and conceptual instruments that act as means of achieving the given purpose in collaboration with other members of the community (e.g., digital production systems). The activity is also tied to its societal and cultural base, including rules (e.g., managerial directives, strategies and business models), community of employees and a division of labour among actors (Engeström, 2014). This basic structure of an activity system will be represented in Figure 2.

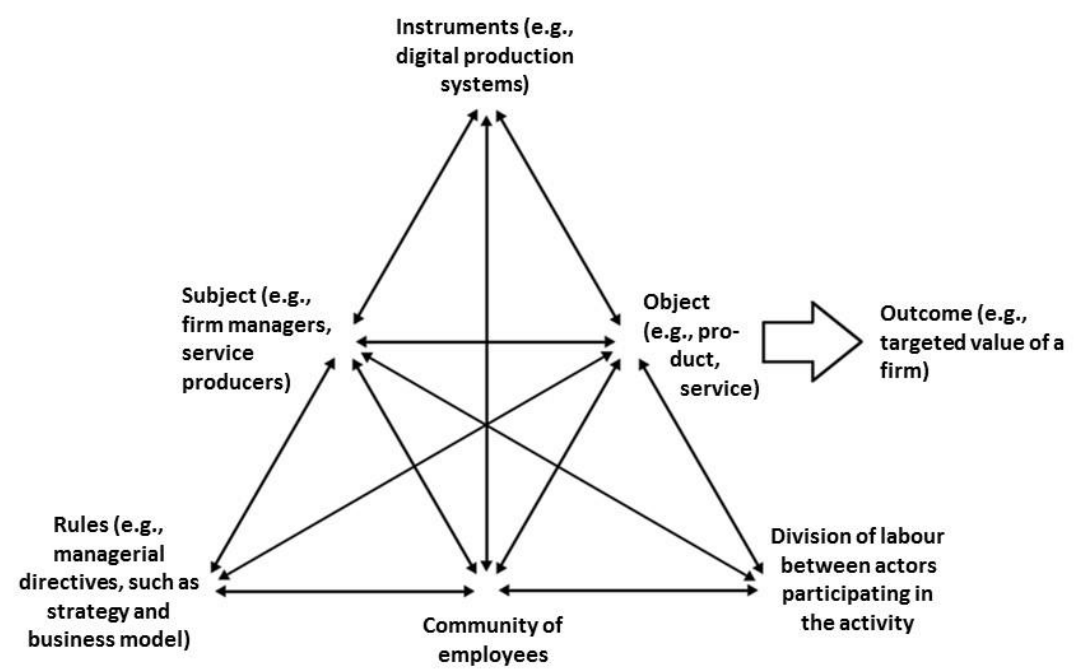

Figure 2. Activity system (adapted from Engeström, 2014). 
The activity system is a systemic entity, meaning that when a change occurs in one component — e.g., a new business concept is introduced into a firm in the form of a rule — it affects all the other components in a dynamic manner. During such processes, elements of the activity system may develop asynchronously, leading to a situation where individual components of the activity are of "different pairs". In activity theory, such tensions produce disturbances (i.e., deviations from normal scripted or sought-after courses of events) that manifest themselves in practical actions of those people involved in the activity in question. In this paper, we will regard early warning signals to be one type of such disturbances. Theoretically, disturbances are called contradictions (Engeström, 2000), i.e., systemic imbalances between the elements of a firm's activity system. The idea is in line with dialectic process theory (Sminia, 2009; Van de Ven \& Poole, 2005) where a company is analyzed in terms of contradictory elements or colliding forces. When these forces are in balance, the organization is stable: everything proceeds smoothly and as anticipated. Change occurs as soon as the balance is upset. The challenge then remains how to analyze the imbalance and how to make necessary corrective actions so as to re-stabilize the activity system again.

In this conception, early warning signals are considered deviations from the planned courses of events in the materialization of the company's targeted value (object) and can thus be interpreted as disturbances within the firm's activity system. Theoretically, they are signs of deeper fundamental imbalances taking place among the elements of an activity system. Early warning signals are thus methodological devices that may be used to understand underlying causes of decline, i.e., persistent "resident pathogens" (Reason, 1990) or "weak points in activity" (Rogalski, 1996) in the firm's activity. Contradictions, in turn, are theoretical interpretations of these warning signs and their successful resolution opens up a way to corporate renewal and recovery.

These activity theoretical ideas can be combined with the strategic management process model presented earlier. When integrated with Figure 1, an altered model of the strategic management process will be attained (see Figure 3). 


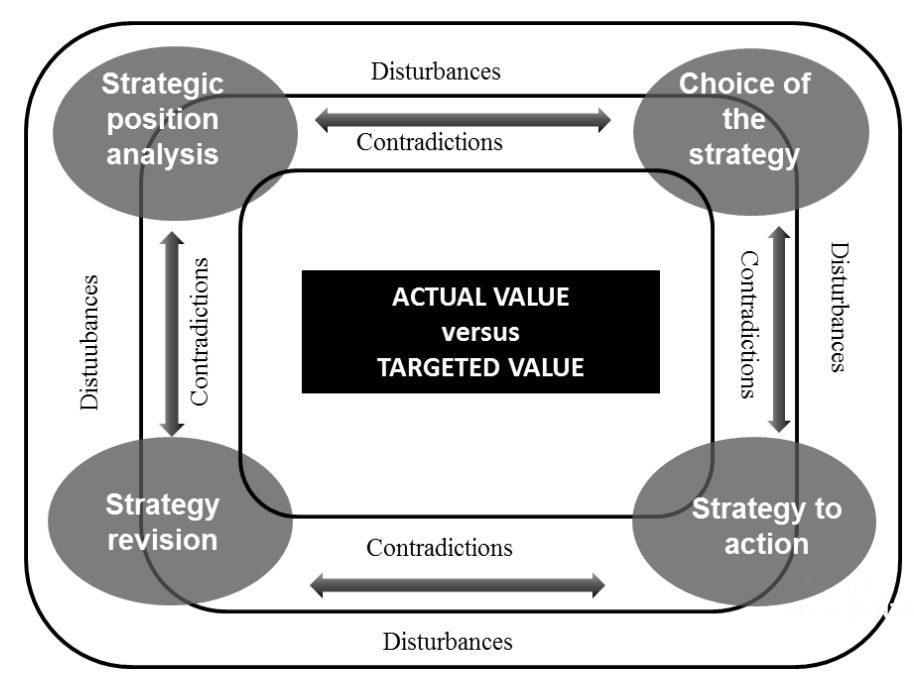

Figure 3. Disturbances and contradictions in the strategic management process.

In Figure 3, we show a situation where the actual value of a company deviates remarkably from its targeted value. This indicates strategy underperformance, i.e., decline of the firm. Disturbances represent early warning signals that may, if noticed, hint to the management about possible underlying problems in the firm's activity. These are conceptualized as contradictions that call for a solution so as to prevent the decline from happening. Most often such disturbances and the related contradictions become evident when one moves from one phase of the strategic management process to another, e.g., when a firm starts to implement a revised strategy. The implementation may prove difficult, however, if the new strategy does not meet real-life conditions (Carroll \& Karim, 2011). In cases like these, the ensuing problems have to be solved, because if they are left unattended, they may escalate and create a crisis. When addressing such problems, we suggest the model of the activity system to be used as a tool to understand where corrective actions should be targeted, i.e., what are the elements of the given activity that are in imbalance thereby creating signs of decline. 
Given that most modern organizations are large and complex entities, and consist of multiple relatively autonomous units, they can be analyzed as interconnected activity systems rather than as single activities. We illustrate this approach in Figure 4 below. In it, one activity system, such as that of management, sets rules for others, such as work units, to follow. When it comes to the relations with external actors (clients, partners), collaboration is formed around a shared object of work that both organizations want to achieve. Contradictions can therefore exist either between different activity systems of a single firm (e.g., between the management group and work unit) or between networked organizations (Engeström, 2014). Also issues ensuing from the external environment of an activity system (e.g., in the form of rules being set) may cause contradictions in another activity, as will be illustrated by our case example. The basic idea about the network of activity systems is pictured in Figure 4 below.

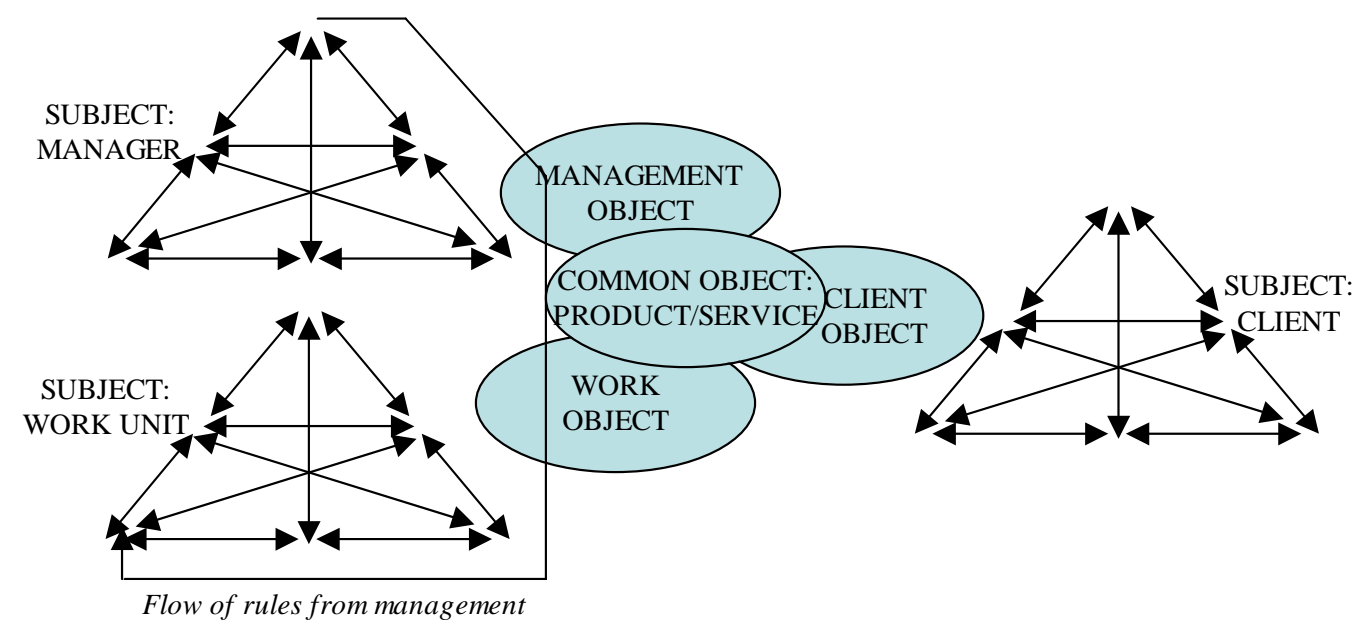

Figure 4. Network of activity systems (Engeström, 2008b).

Next, we will demonstrate the use of the proposed theoretical approach by presenting an illustrative case example where early warning signals act as hints about strategy underperformance in the strategy to action phase. With the help of the case, we will demonstrate how top management first 
blames supervisors for unsuccessful performance and when the supervisory remedies prove insufficient, puts the blame on business processes and customer service personnel. Because the management thus is incapable of analyzing the fundamental contradictions behind the visible warning signs, the company falls into decline and finally ends up in a crisis. The case example will then show how activity theoretical conceptualization could have helped to make better sense of the problems behind the apparent early warning signals.

\section{Data and methods}

\subsection{Data}

Our case example comes from a study of a service company which will be called, hereafter, Service Company, applying a growth strategy. The data consists of eight theme interviews, four of which represented the members of the firm's management group, two team leaders of service production and two accountants producing services for customers. The length of the interviews was roughly an hour. We interviewed our informants in a semi-structured manner focusing attention on the firm's growth strategy and problems encountered in its materialization. The interviews were based on an outline prepared before the discussion, but we allowed the interviewees to shape the course of the conversation and to take up any issues they considered important from their perspectives. The variety of informants interviewed provided what we consider a multifaceted and rich understanding of the problems encountered by the employees of the firm, thereby providing an apt opportunity to analyze early warning signals of the company's decline. We will summarize the data in the following Table 1. 


\begin{tabular}{|l|c|l|}
\hline \multicolumn{1}{|c|}{ Interviewee } & $\begin{array}{c}\text { Length } \\
\text { (minutes) }\end{array}$ & \multicolumn{1}{|c|}{$\begin{array}{c}\text { Most important issues/disturbances mentioned during } \\
\text { interview }\end{array}$} \\
\hline $\begin{array}{l}\text { Management group } \\
\text { member 1 }\end{array}$ & 48 & $\begin{array}{l}\text { Inadequate operation of compensation policy in service } \\
\text { production }\end{array}$ \\
\hline $\begin{array}{l}\text { Management group } \\
\text { member 2 }\end{array}$ & 41 & $\begin{array}{l}\text { Inadequate operation of compensation policy in service } \\
\text { production }\end{array}$ \\
\hline $\begin{array}{l}\text { Management group } \\
\text { member 3 }\end{array}$ & 58 & $\begin{array}{l}\text { Inadequate operation of compensation policy in service } \\
\text { production }\end{array}$ \\
\hline $\begin{array}{l}\text { Management group } \\
\text { member 4 }\end{array}$ & 51 & $\begin{array}{l}\text { Ladequate operation of compensation policy in service } \\
\text { production }\end{array}$ \\
\hline $\begin{array}{l}\text { Team leader in service } \\
\text { production 1 }\end{array}$ & 61 & $\begin{array}{l}\text { Lack of bottom-up communication between experts and } \\
\text { management }\end{array}$ \\
\hline $\begin{array}{l}\text { Team leader in service } \\
\text { production 2 }\end{array}$ & 63 & Tight time schedules \\
\hline Accountant 1 & 58 & Tight time schedules \\
\hline Accountant 2 &
\end{tabular}

Table 1. Data of this study.

\subsection{Methods}

After the interviews, we transcribed the data, analyzed its content according to procedures of qualitative content analysis (Saldaña, 2012; Krippendorf, 2013) and interpreted the results of the analysis with the help of activity theoretical concepts. The content analysis proceeded through four phases depicted in Figure 5 below. First, we produced initial disturbance categories by inductively coding the interview transcripts. At this stage, we paid attention to the descriptions of problems encountered by the interviewees in the service production. Second, we aggregated these inductive categories into broader classes of disturbances. In the third phase, we proceeded to the activity theoretical interpretation of the results of the content analysis. Here, we interpreted the disturbance classes in terms of contradictions and placed these into the service producers' activity system. In the fourth phase of analysis, we considered how these contradictions were present in the management group's activity system. Next, we will describe these phases in more detail. 


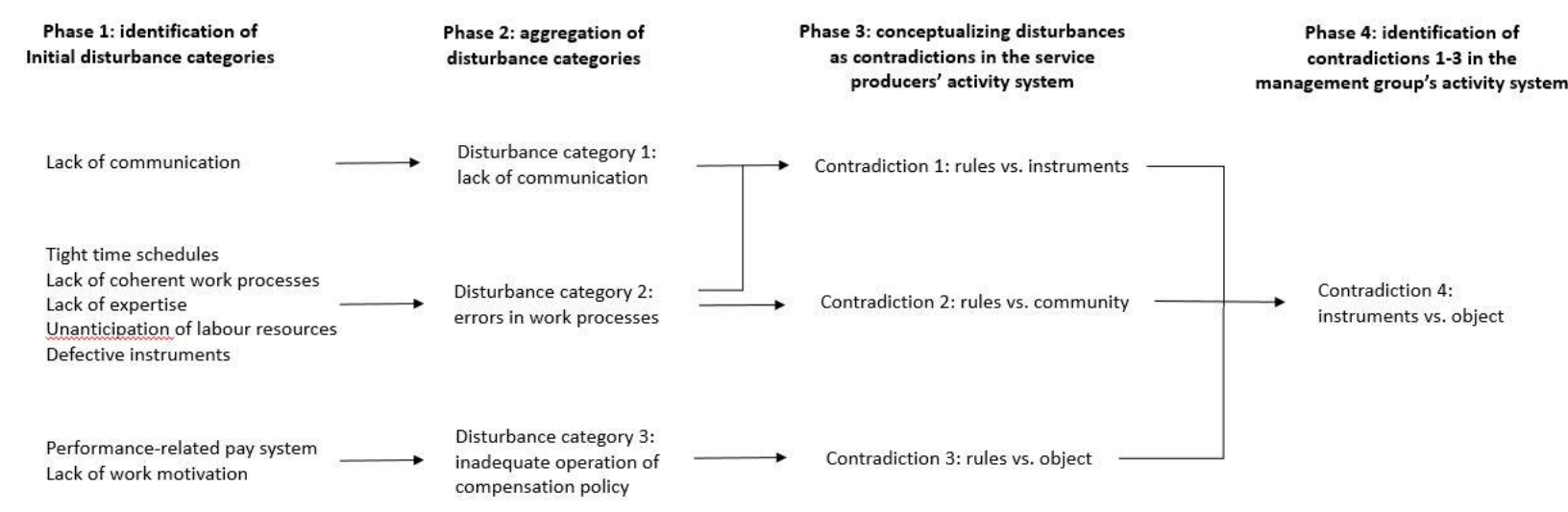

Figure 5. A schematic representation of data analysis and interpretation.

In the first phase of analysis, we identified all the data segments that could be regarded as descriptions of disturbances in service production, named these according to their empirical content and collected them into a table. A short example of such tabulated list of coded data is represented in Table 2 below.

\begin{tabular}{|c|l|l|}
\hline Nr. & \multicolumn{1}{|c|}{ Data Excerpt } & \multicolumn{1}{c|}{ Coding } \\
\hline 5 & $\begin{array}{l}\text { In an ideal situation, we would have coherent work practices, that is, what if } \\
\text { the project had been started earlier. Could that have been possible? } \\
\text { Afterwards, one can make up whatever, but in a decision situation one makes } \\
\text { the decision which seems to be the best at that point in time. }\end{array}$ & $\begin{array}{l}\text { Lack of coherent work } \\
\text { processes }\end{array}$ \\
\hline 6 & $\begin{array}{l}\text { The top management has brought about that most of us have got other } \\
\text { countries and firms to manage. Gosh, what time? It has been discussed in the } \\
\text { management group, that is, I told them that I am not going to do it. I'll let } \\
\text { someone else take care of that. }\end{array}$ & Lack of time \\
\hline 7 & $\begin{array}{l}\text { The management problem: the level and quality. Former experts have been } \\
\text { [working] in a group of five, now they should manage 25 former workmates. } \\
\text { It's not easy. It makes no sense to make experts manage others. In this field, } \\
\text { very few dream about being a manager. [Managers] must be hired from } \\
\text { outside. There have not been hired enough [managers]. }\end{array}$ & $\begin{array}{l}\text { Experts are not the best } \\
\text { managers }\end{array}$ \\
\hline
\end{tabular}

Table 2. An example of data coding.

In this phase, we also identified those disturbances that were most frequently mentioned by the interviewees. These types of disturbances included, e.g., tight time schedules, lack of 
communication, lack of coherent work processes, lack of expertise, non-anticipation of labour resources and performance-related pay system.

In the second phase of analysis, we organized the coded data segments systematically into broader analytical classes, named these according to their contents and arranged them again in tabular form. At this stage, those disturbances that were mentioned repeatedly by multiple interviewees were considered problems that were strongly and widely experienced within the firm. We constructed three main disturbance categories in this phase of analysis: 1) Lack of communication across organizational layers (33 disturbance descriptions), 2) errors in work processes (50 disturbance descriptions), and 3) the inadequate operation of the compensation policy (33 disturbance descriptions).

In the third phase, we interpreted the results achieved in the content analysis with the help of activity theoretical concepts. The goal of this procedure was to move from the inductive data analysis to its activity theoretical interpretation, which we achieved by conceptualizing the three aggregated disturbance categories in terms of contradictions existing between various elements of the service producers' activity system.

In the fourth phase of analysis, we continued with the activity theoretical interpretation of the disturbances by looking at how the contradictions experienced by the service producers were visible in the management group's activity system. The idea behind locating the contradictions in these two activity systems was to make visible the different perspectives of the service production and top management in terms of the roots of the warning signals experienced initially by the service producers and recognized only later by the managers.

In what follows, we will provide a short introduction to the history of the studied firm in order to facilitate understanding of the empirical context of the analysis, i.e. the implementation of the new strategy. After that, we will present our results as organized according to 1) the disturbance categories found in the data, and 2) the contradictions present in the two activity systems. 


\section{Disturbances and contradictions in Service Company}

\subsection{Implementation of new strategy in Service Company}

At the time of the study, Service Company was in the middle of a growth strategy implementation with a turnover of up to EUR 90 million and over 1,000 members of personnel. Five years earlier, it had made its first big acquisition. The growth strategy was to be continued by acquiring small business units and by increasing the number of customers. The new organization structure consisted of five management layers instead of the previous two. The purpose of the structure was to facilitate the service production by centralizing power and developing concepts which could efficiently be utilized in service production. The top management did not believe in frontline competence to perceive the overall picture and develop work processes. The prevailing management methods were focused on streamlined implementation of the strategy. The formation of a team organization was one significant development project. The new team managers did continue to serve customers but 30 per cent of their time was supposed to be devoted to supervisory duties with five to eight subordinates. The purpose of the team structure was to improve the quality of leadership and increase organizational learning.

New work practices were implemented by professional work groups by dropping the new concept down from one hierarchical level to another together with a detailed implementation plan. Stratifying the work processes and measuring the efficiency of the work modules was the focus. The work descriptions and instruments were standardized. The business concept was largely based on the development of digital production systems causing a significant change in the division of labour among service providers (the accountants). Earlier, each person was responsible for the entire service 
process for one customer. Now, there was a team consisting of several accountants and each team member performed some module of the entire production process. This enabled less competent and cheaper employees to accomplish a big part of the service. The number of competent personnel in relation to turnover was reduced because the new division of labour and clear work process handbooks enabled the recruitment of less competent and cheaper employees. However, one experienced person was named as the person responsible for a particular customer relationship despite the fact that (s)he did not necessarily perform even a part of the actual service production. The work developers considered that this kind of division of labour would increase job satisfaction among experienced employees as they no longer had to work with routine tasks.

The rewarding structure used a balanced-scorecard-based profit card (Kaplan and Norton, 1996) derived from strategic objectives. The metrics consisted of personnel satisfaction, turnover growth, customer satisfaction and different efficiency and profit targets. The fixed part of the salary was targeted to be as low as possible and the flexible part based on individual, team and company performance. One goal of the renewed compensation policy was to ensure that employees who performed well would not have to subsidize those who performed badly.

\subsection{Disturbances in strategy implementation phase}

The problems of service production encountered by the interviewees were organized into three major disturbance categories: 1) lack of communication across organizational layers, 2) errors in work processes caused by the new team structure, and 3) inadequate operation of the compensation policy due to differing goals of the employees vis-á-vis those of the management. Next, each of these will be summarized, respectively.

\subsubsection{Disturbance category 1: lack of communication}


The first disturbance category, the lack of communication across the organizational hierarchy, originated from the new organizational structure, which changed the roles of middle managers leading to a situation where department managers lost their power to upper level managers; each middle manager was "just one team leader among many", representing the lowest management layer of the five in total. A service producer described:

We are having terribly many managers nowadays. I feel like we are having extremely many bosses. I don't understand, but I have thought that I don't have to. I don't even know how many management layers there are. (Data excerpt 1, accountant)

Furthermore, the team leaders were not allowed to make decisions that would have been needed in the middle of the organizational change that was taking place in the firm. Even in critical situations where the new systems and principles caused serious problems for customers, the employees did not get their messages through the management; these either stopped at some of the middle management layers or changed in form and degree of severity. Moreover, the lack of shared procedures in service production would have necessitated increased levels of communication, which was lacking, however. The service producers thus felt that they were not listened to:

We are having a lot of mistakes in management, wrong decisions, wrong solutions, without really listening to, without respecting the experience. (...) Is there anyone who cares about our ideas? It would be good to have information going from the bottom to the top and from the top to the bottom. Especially from the bottom to the top. There might be really good ideas there that are worth communicating. (Data excerpt 2, team leader)

\subsubsection{Disturbance category 2: errors in work processes}

The second disturbance category was errors in work processes. Although the errors were caused by the new team structure, the top management considered these resulting from leadership problems. In addition, time management of service producers proved challenging: two different methods - the old 
and the new-were used, causing uneven workloads among the employees. The profit targets were also so hard that there was no space for upfront recruitment causing overload for employees and situations where they confronted tasks that were impossible to accomplish. Two team leaders described the situation:

We should have a front-heavy recruitment process. [Now,] we take in new customers without knowing their processes, without knowing the customer. (Data excerpt 3, team leader)

Now we are having a kind of fire-fighting approach. When a new customer comes [in we ask], do we have staff enough, by the way? No. Ok, let's take it anyway. (Data excerpt 4, management group member)

According to the accountants, serving the customers had to be done simultaneously with other work duties, including the increased amount of communication, correcting errors and learning new ways of working. The situation was further aggravated, because the company recruited new employees but the competent ones did not have time to teach the newcomers. One accountant said:

In my opinion, we should have more time, especially after P [a resigned employee]... We should have someone who would look after. Someone should be looking after. Such things have been found that sometimes I have sweated blood... Uuh. (Data excerpt 5, accountant)

\subsubsection{Disturbance category 3: inadequate operation of compensation policy}

The third disturbance category was inadequate operation of the compensation policy. This was due to the fact that the service producers were not used to intensive monitoring and profit follow-up, which caused the compensation system to function poorly as a motivating factor; the employees were more interested in making customers satisfied than having higher salaries for greater invoicing levels. The employees thus applied the old working methods despite the need to adopt the new ones. The management did not understand, however, that job satisfaction among the service producers arose from successful customer service and not from higher pay. As the customer work was reduced, and 
they were served poorly, the relationship between the accountants and managers became strained. Instead of acknowledging the service producers' perspective, the management group worried about the lack of unified work practices and organization-wide performance-based salary system, indicating that it believed these would solve the greatest problems. According to one manager:

The personal differences in the performance level are bigger than differences in salaries, which means that the best subsidize those who don't make it. (Data excerpt 6, management group member)

\subsection{Interpretation of disturbances by using concepts of contradiction and activity system}

To better understand the significance of the disturbances illustrated above, we will next apply the concepts of contradiction and activity system to further theorize about the disturbances found in Service Company. Hence, attention will be paid to the relationship between the key components of the firm's activity so as to provide a deeper understanding of the causes behind the disturbance, i.e., early warning signals, reported above.

The activity system of service production consisted of experienced employees and their immediate superiors (subjects in the activity system, see Figure 2) who, in collaboration with others, provided services to customers (object). The tools used in this work included new digital systems by means of which quality service with a good profit margin and satisfied customers was to be achieved. The rules that directed the work consisted of legal statutes and management instructions, including the new business concept. The division of labour was defined primarily by the employees' expertise. The top management's activity system, in turn, can be regarded as one focusing on managing service production and implementing changes, i.e. the new business concept, production system and team structure, all of which originated from the altered firm strategy. In the following, the disturbances 
reported above will be interpreted in terms of contradictions present in the service producers' activity system (contradictions 1-3) and management group's activity system (contradiction 4).

\subsubsection{Contradiction 1: rules vs. instruments}

This first contradiction of the service producers' activity system was related to the disturbance categories 1 and 2 and occurred between rules and instruments. The altered business concept designed by the management, i.e., the new rule according to which the firm was to be operated, did not facilitate the service producers to do their work effectively and error-free, but was instead experienced by them as a limiting factor. The highly standardized procedures determined by the concept were considered time consuming and they did not respond to the customer needs of different business units. From the service producers' perspective, the customization of the standardized service delivery would have been needed but was not allowed, according to the concept. Furthermore, because work processes determined by the business concept and facilitated by the new digital production system were modularized, the need for communication and documentation between team members in service production increased. This took time and the employees were not used to it, which, as a consequence, caused misunderstandings and errors in work processes. In the new production system, errors were however easily overlooked and their detection took more time than earlier. Moreover, because the old and new software and work methods were applied at once, time management proved difficult.

\subsubsection{Contradiction 2: rules vs. community}


The second contradiction, associated with the disturbance category 2, can be identified as being between rules and work community: The altered business concept introduced by the management as a rule into the service providers' activity system was in conflict with the existing personnel structure of the activity, one which originally had been well aligned with the goals of the work. As the model significantly changed the structure of the work community, meeting of the actual goals of service production became difficult. This was due to the fact that the level of professional skills of the accountants decreased, causing a situation where too few competent employees were involved in producing services. The new personnel structure thus did not enable the more extensive use of lowskilled and cheap employees, as was sought by the management, but increased the competent employees' work load instead: There existed a desperate need for experienced employees who would have been able to solve the unanticipated problems, correct the errors and provide orientation for new, just-recruited personnel, but these people were too few.

\subsubsection{Contradiction 3: rules vs. object}

The third contradiction, related to the disturbance category 3, can be identified as being between rules and object of work, as the principles of the new business concept were also in conflict with the employees' motive for work (i.e. customer satisfaction): The employees were interested in serving the customers, but the customer work was reduced as a consequence of process stratification and the introduction of team work. Moreover, the employees did not have customers of their own anymore. The reward from the work did not thus come from customer interaction and feedback, which used to be the primary motivating factor, but was expected to be derived from the performance assessment system based on invoicing. In addition, the modularized work processes created situations where the employees had to trust in the previous process phases accomplished by other persons, perhaps the ones less-skilled. The competent employees did not shun the routine work as the management had 
assumed and did not feel the need to reorganize the division of labour and transfer the routine tasks to less-skilled employees. The employees had also lost the power to develop their own work, which resulted in resistance against the goals of the management.

\subsubsection{Contradiction 4: instruments vs. object}

The above-mentioned three contradictions (and the related disturbance categories) we identified in the service production appeared in the top management's activity system as a contradiction between the instruments and object of work: It was the management's purpose to materialize the new strategy with the help of the altered business concept, which then reformed the service producers' work activity. As it did so, the contradiction 4 found in the management's activity system became transferred and transformed into three distinct contradictions of the service production thereby causing severe difficulties in the daily work processes of service production. In other words, the contradictions experienced by the service producers were rooted in the mismatch between the instruments used by the management and their object of work, i.e. using a new business model to manage the service production in order to meet the strategic objectives of increasing productivity by means of centralizing power and developing new concepts of service production. The four contradictions and their relationship we described above are represented in Figure 6 below. 


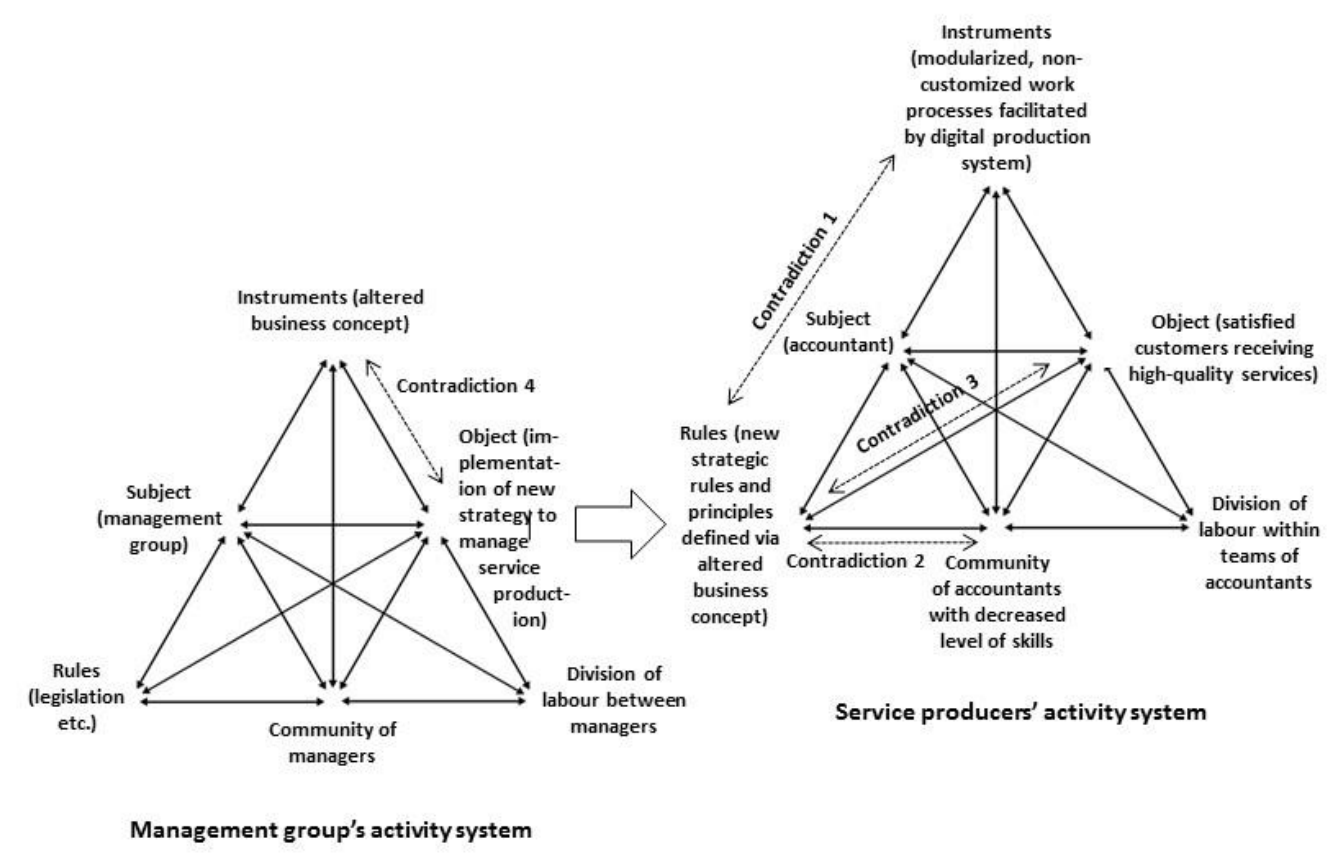

Figure 6. Contradictions in Service Company.

\subsection{Relationship between contradictions and firm strategy}

All of the contradictions discussed above were in direct connection with the critical success factors of the firm; they occurred repeatedly, concerned economic performance and customer satisfaction, were related to the company's strategy, affected many functions within it, and were widely perceived by the work community as problems. From the management group's point of view, the problems were, however, associated with team leaders' incapability to manage time in service production, in addition to which insufficient implementation of unified work principles and compensation systems were regarded as problems. The management group worked towards solving these difficulties that were 
not really the root of the firm's decline. The top management claimed that if the middle management had paid attention to leadership (e.g. organizing the work, motivating the personnel and giving encouragement), the employees' resistance would have been minimized and the implementation of the new business concept with increased productivity would have been successful. Therefore, the underlying reasons for the decline remained unattended.

The analysis facilitated by activity theoretical conceptualization thus provides a more foundational and helpful understanding of the causes of decline than can be achieved by focusing solely on early warning signals (i.e., disturbances). In addition to resonating many of the signals mentioned by Lorange and Nelson (1987), among others, the approach suggested here is capable of explaining the systemic causes behind the visible signs, the imbalances between elements of the local operative context that give rise to visible problems. If the analysis of contradictions is combined with the phases of strategic management process described in Figure 3, one can see that the original strategic choice was a phase in which the key framework according to which service production had to be conducted was defined. This was also the phase where the problems ultimately originated, instead of the strategy implementation phase, which was singled out by the management as the key problem. We thus maintain that the logical outcome of this is that the successful solution of the problems should, likewise, be sought during the strategy revision rather than the implementation phase.

\section{Conclusion}

In this article, we stressed the need to pay more attention to early warning signals of corporate decline and sought ways for further theorizing these with the help of activity theory. The reason for doing so was our conviction that if the top management of a firm fails to address such signals, the situa- 
tion may turn critical; the further the company enters the stage of decline, the more difficult and expensive the remedies will become. The adequate and valid managerial analysis of potential signs of decline is therefore a necessity for a firm to succeed, but has been neglected so far in strategy process research. To achieve a more fundamental understanding of the early warning signals of decline, we thus developed an analytical perspective where these were first identified with the activity theoretical notion of disturbances and then interpreted theoretically as contradictions, i.e., developmental dynamical tensions present in local activity systems. These crucial tensions were then discussed in relation to phases of a strategic management process and, finally, the empirical example of Service Company was provided to illustrate the use of the analytical perspective so developed.

In our view, the significance of the activity theoretical conceptualization is to prepare a way to overcome what Weitzel and Jonsson (1989) called the blinded state of decline. In the studied case example, this occurred especially in relation to the management's non-awareness of the contradiction concerning the employees' real interest for work. This and other contradictions identified in the analysis then deepened during the strategy to action phase as the management did not react to the problems that occurred in production. This corresponds to Weitzel and Jonsson's inaction state of the company's decline, where the organization recognizes the need for change but takes no action. Later on, the leadership was intensified but remained committed to the existing course of managerial action. When the situation approached the crisis state, the standards for leadership got more demanding, which caused a situation where inexperienced superiors who were supposed to lead everyday work could not solve the prolonged problems in service production. In Weitzel and Jonsson's terminology, this can be defined as a faulty action state where the company takes action, which remains inappropriate. Over time, warning signals of less than successful performance continued to multiply but the faulty action did not solve the root problems behind these, therefore leading the company into a serious crisis. 
So, although the model of decline presented by Weitzel and Jonsson (1989) provides adequate phases through which decline proceeds, it says very little on how the development could be turned from decline into recovery. The current paper, in turn, maintains that activity-theoretical perspective is useful here. By fostering understanding of the underlying systemic tensions (i.e. contradictions) that lay beneath the more visible warning signals (i.e., disturbances), the theory prepares the ground for understanding organizational renewal: The concepts of activity system and contradiction will help to fill gaps in strategy process research and increase sensitivity to serious problems that restrain companies in reaching their targeted objectives. A conceptual model of the activity system is particularly useful if one wants to make sense of systemic factors behind seemingly accidental disturbances and deviations (early warning signals) occurring in the daily practices of organizations, and start working towards solving them (Engeström, 2008a). Without appropriate theoretical perspective, such tensions often remain challenging to detect and difficult to manage. As many analyses already indicate, the activity theoretical conceptuality has proved useful in organizational analysis (e.g., Kajamaa 2015) and should thus be applied to understanding early warning signals, too.

We have also argued for the need to understand the contradictions in terms of phases in the strategic management process so as to determine the stage of the firm's development wherein the problems originate. Analysing the strategic management process with its various sub-processes enables more explicit localization of the contradictions and creates the groundwork for their accurate solution efforts. When it comes, for instance, to strategy revision needed in the face of transformed environmental conditions, it would be crucial for companies to understand if the board really is revising the strategy to achieve the set targets or if it is just streamlining the implementation of the existing strategy under the framework of prevailing performance objectives. Therefore, by combining the analysis of the strategic management process with activity theory, the impact of complex social processes in a firm can be better identified. 
When it comes to practical management of a company, the board of directors is the closest to the resolution of contradictions, i.e., the causes behind early warning signals, as it is responsible for deciding how the strategy will be executed. Despite the fact that the strategic role played by the board has already been addressed (Wiersema, 2002; Garrat, 2003; Patton \& Baker, 1987; Eisenhardt, 1990; Dalton et al., 1998; Judge \& Zeithaml, 1992), its strategic role should in our view receive more attention, especially from the activity theoretical perspective. Otherwise, one may run the risk of losing crucial information about the top managerial activities that all too often remain treated as "a black box" without adequately understanding their role in the production of developmental contradictions of firm development. And, without proper theoretical understanding about interaction between the board and the employees of a company, it is not possible to draw reliable conclusions about prevailing organization-specific disturbances and contradictions behind these before the company reaches the point of crisis. The call for in-depth activity theoretical analysis of the early warning signals of corporate decline therefore continues.

\section{References}

Adler, P.S. (2006) 'From labor process to activity theory', In P. Sawchuk, M. Elhammoumi \& N. Duarte (Eds.), Critical perspectives on activity theory, education and work: an international collection, pp.160-193. Cambridge University Press.

Barker, V. and Mone, M. (1994) 'Retrenchment: cause of turnaround or consequence of decline?' Strategic Management Journal, Vol. 15, pp.395-405. doi: 10.1002/smj.4250150506

Blackler, F., Crump, N. and McDonald, S. (2000) 'Organizing processes in complex activity networks', Organization, Vol. 7, 277-300. doi: 10.1177/135050840072005

Boynton, A. and Victor, B. (1991) 'Beyond flexibility: building and managing the dynamically stable organization', California Management Review, Vol. 34, pp.53-66. doi: 10.2307/41166683 
Cameron, K., Myung U. and David A. (1987) 'Organizational effects of decline and turbulence', Administrative Science Quarterly, Vol. 32, pp.222-240. doi: 10.2307/2393127

Carroll, T.N. and Karim, S. (2011) ‘A framework of organisations as dynamic structures', International Journal Strategic Change Management, Vol. 3, pp.230-246. doi: 10.1504/IJSCM.2011.041828

Chong, J. (2004) 'Six steps to better crisis management', Journal of Business Strategy, Vol. 25, pp.43-46. doi: 10.1108/02756660410525407

Cummings, T., Blumenthal, J. and Greiner, L. (1983) 'Managing organizational decline: the case for transorganizational systems', Human Resource Management, Vol. 22, pp.377-390. doi: 10.1002/hrm.3930220406

D'Aveni, R. (1989) 'The aftermath of organizational decline: a longitudinal study of the strategic and managerial characteristics of declining firms', Academy of Management Journal, Vol. 32, pp.577-605. doi: 10.2307/256435

Dalton, D., Daily, C, Ellstrand, A. and Johnsson, I. (1998) 'Meta-analytic reviews of board composition, leadership structure and financial performance', Strategic Management Journal, Vol. 19, pp.269-290. doi: 10.1002/(SICI)1097-0266(199803)19:3<269::AIDSMJ950>3.0.CO;2-K

David, F. (2011) Strategic management: concepts and cases, Prentice Hall, New Jersey.

DeVaughn, M. and Leary, M. (2010). Antecedents of failure for newly chartered banks in the U.S. banking industry. Group \& Organization Management, Vol. 35, pp.666-695. doi: $10.1177 / 1059601110381495$

Eisenhardt, K. (1990) 'Speed and strategic choice: how managers accelerate decision making', California Management Review, Vol. 32, pp.39-54. doi: 10.2307/41166616

Engeström, Y. (2000) 'Activity theory as a framework for analysing and redesigning work', Ergonomics, Vol. 43, pp.960-974. doi: 10.1080/001401300409143 
Engeström, Y. (2005) Developmental work research: expanding activity in practice, Lehmanns, Berlin.

Engeström, Y. (2008a) From teams to knots: activity theoretical studies of collaboration and learning at work, Cambridge University Press, Cambridge.

Engeström, Y. (2008b, September), 'The future of activity theory: a rough draft. Keynote presentation at the ISCAR Conference, University of California, San Diego, USA. Retrieved from http://lchc.ucsd.edu/mca/Paper/ISCARkeyEngestrom.pdf.

Engeström, Y. (2014) Learning by expanding: an activity-theoretical approach to developmental research, Second Edition, Cambridge University Press, Cambridge.

Engeström, Y., Miettinen, R. and Punamäki, R.-L. (Eds.) (1999) Perspectives on activity theory, Cambridge University Press, New York.

Ericson, M. (2014) 'On the dynamics of fluidity and open-endedness of strategy process toward a strategy-as-practicing conceptualization', Scandinavian Journal of Management, Vol. 30, pp.1-15. doi: 10.1016/j.scaman.2013.05.003

Foot, K. (2002) 'Pursuing an evolving object: a case study in object formation and identification', Mind, Culture, \& Activity, Vol. 9, pp.132-149. doi: 10.1207/S15327884MCA0902_04

Garratt, B. (2003) Thin on top. Why corporate governance matters and how to measure and improve board performance, Nicholas Brealey Publishing, London.

Ghoshal, S., Lampel, J., Mintzberg, H. and Quinn, J. B. (Eds.) (2013) The strategy process: concepts, context, cases, Prentice Hall, Harlow.

Hambrick, D. and D’Aveni, R. (1988) 'Large corporate failures as downward spirals', Administrative Science Quarterly, Vol. 33, pp.1-23. doi: 10.2307/2392853

Heine, K. and Rindfleisch, H. (2013) 'Organizational decline: a synthesis of insights from organizational ecology, path dependence and the resource-based view', Journal of Organizational Change Management, Vol. 26, pp.8-28. doi: 10.2139/ssrn.2178991 
Johnson, G., Scholes, K. and Whittington, R. (2008) Exploring corporate strategy, Financial times Prentice Hall, Harlow.

Judge, W.Q. and Zeithaml, C. P. (1992) 'Institutional and strategic choice perspectives on board involvement in the strategic decision process', The Academy of Management Journal, Vol. 35, pp.766-794. doi: 10.2307/256315

Kajamaa, A. (2015) 'Collaborative work development as a resource for innovation and quality improvement in health care: an example from a hospital surgery', In S. Gurtner \& K. Soyez (Eds.), Challenges and opportunities in health care management, pp.123-134. Springer.

Kaplan, R. and Norton, D. (1996). The balanced scorecard: translating the strategy into action, Harvard Business Review Press, Boston.

Kerosuo, H., Kajamaa, A. and Engeström, Y. (2010) 'Expansive development through the change laboratory method: example from Finnish health care', In K. Müller et al. (Eds.), Social dimension of innovation, Center for Economic Studies, College of Economics and Management, Linde nakladatelstvi, s.r.o, Prague, pp.106-114.

Krippendorf, K. (2013) Content analysis: an introduction to its methodology, Sage, Los Angeles. Langley, A., Smallman, C., Tsoukas, H. and van de Ven, A. (2013) 'Process studies of change in organization and management: unveiling temporality, activity, and flow', Academy of Management Journal, Vol. 56, pp.1-13. doi: 10.5465/amj.2013.4001

Leontjev, A. (1978). Activity, consciousness, personality, Englewood cliffs, Prentice Hall, New Jersey.

Lorange, P. and Nelson, R. (1987) 'How to recognize - and avoid - organizational decline', Sloan Management Review, Vol. 28, pp.41-48.

Maitlis, S. and Lawrence, T.B. (2003) 'Orchestral manoeuvres in the dark: understanding failure in organizational strategizing', Journal of Management Studies, Vol. 40, pp.109-139. doi: 10.1111/1467-6486.t01-2-00006 
McKinley, W. (1993) 'Organizational decline and adaptation: theoretical controversies', Organization Science, Vol. 4, pp.1-9. doi: 10.1287/orsc.4.1.1

McKinley, W., Latham, S. and Braun, M. (2014) 'Organizational decline and innovation: turnarounds and downward spirals', Academy of Management Review, Vol. 39, pp.88-110. doi: 10.5465/amr.2011.0356

Mellahi, K. (2005) 'The dynamics of boards of directors in failing organizations', Long Range Planning, Vol. 38, pp.261-279. doi: 10.1016/j.lrp.2005.04.001

Miettinen, R. (2005) 'Object of activity and individual motivation', Mind, Culture, and Activity, Vol. 12,pp.52-69. doi: 10.1207/s 15327884mca1201_5

Milenković, G. (2001) 'Early warning of organisational crises: a research project from the international air express industry', Journal of Communication Management, Vol. 5, pp.360373. doi: 10.1108/13632540110806884

Mintzberg, H. \& Quinn, J. (1991) The strategy process: concepts, contexts, cases, Englewood Cliffs, Prentice Hall, New Jersey.

Mitroff, I. (1988) 'Crisis management: cutting through the confusion', Sloan Management Review, Vol. 29, pp.15-20.

Mocciaro Li Destri, A. and Dagnino, G.B. (2012) 'Learning to synthesise contradictions: an Austrian approach to bridging time concepts in the strategic theory of the firm', International Journal of Strategic Change Management, Vol. 4, pp.99-128. doi: 10.1504/IJSCM.2012.046501

Patton, A. and Baker, J. (1987) 'Why won't directors rock the boat?' Harvard Business Review, Vol. 65, pp.10-18. doi: 10.1225/87609

Pettigrew, A. (1992) 'The character and significance of strategy process research', Strategic Management Journal, Vol. 13, pp.5-16. doi: 10.1002/smj.4250130903

Reason, J. (1990) Human error, Cambridge University Press, Cambridge. 
Robbins, D. and Pearce, J. (1992) 'Turnaround: retrenchment and recovery', Strategic Management Journal, Vol. 13, pp.287-309. doi: 10.1002/smj.4250130404

Rothaermel, F. (2012) Strategic management: concepts and cases, Irwin /McGraw-Hill, Boston.

Rogalski, J. (1996) 'Co-operation processes in dynamic environment management: evolution through training experienced pilots in flying a highly automated aircraft', Acta Psychologica, Vol. 92, pp.273-295. doi: 10.1016/0001-6918(95)00064-X

Saldaña, J. (2012) The coding manual for qualitative researcher, Sage, Los Angeles.

Sheaffer, Z., Richardson, B. and Rosenblatt, Z. (1998) 'Early-warning-signals management: a lesson from the Barings crisis', Journal of Contingencies and Crisis Management, Vol. 6, pp.1-22. doi: $10.1111 / 1468-5973.00064$

Scherrer, P. (2003) ‘Management turnarounds: diagnosing business ailments', Corporate Governance: The International Journal of Business in Society, Vol. 3, pp.52-62. doi: $10.1108 / 14720700310497122$

Shanley, M. and Peteraf, M. (2006) 'The centrality of process', International Journal of Strategic Change Management, Vol. 1, pp. 4-19. doi: 10.1504/IJSCM.2006.011098

Sminia, H. (2009) 'Process research in strategy formation: theory, methodology and relevance', International Journal of Management Reviews, Vol. 11, pp.97-125. doi: 10.1111/j.14682370.2008.00253.x

Teräs, M. (2007) Intercultural learning and hybridity in the culture laboratory, University of Helsinki, Helsinki.

Thompson, J. and Martin, F. (2010) Strategic management: awareness \& change, Hong Kong: Cengage Learning EMEA.

Vaara, E., and Whittington, R. (2012) 'Strategy-as-practice: taking social practices seriously', Academy of Management Annals, Vol. 6, pp.285-336. 
Van de Ven, A.H. \& Poole, M.S. (2005) 'Alternative approaches for studying organizational change', Organization Studies, Vol. 26, pp.1377-1404. doi: 10.1177/0170840605056907

Vygotsky, L. (1978) Mind in society: the development of higher psychological processes, Harvard University Press, Cambridge.

Weitzel, W. and Jonsson, E. (1989) 'Decline in organizations: a literature integration and extension', Administrative Science Quarterly, Vol. 34, pp.91-109. doi: 10.2307/2392987

Whetten, D. (1987) 'Organizational growth and decline processes', Annual Review of Sociology, Vol. 13, pp.335-358. doi: 13.080187.002003

Wiersema, M. (2002) 'Holes at the top: why CEO firings backfire', Harvard Business Review, Vol. 80, pp.70-79. doi: $10.1225 / 2357$

Williams, T., Klakegg, O., Walker, D., Andersen, B. and Magnussen, O. (2012) 'Identifying and acting on early warning signs in complex projects', Project Management Journal, Vol. 43, pp.37-53. doi: 10.1002/pmj.21259 